\title{
Flow-Duration Curves
}

Manual of Hydrology: Part 2. Low-Flow Techniques

GEOLOGICAL SURVEY WATER-SUPPLY PAPER 1542-A

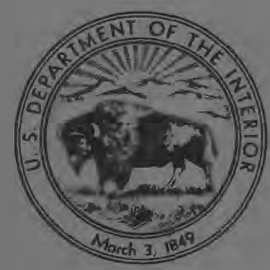




\section{Flow-Duration Curves}

By JAMES K. SEARCY

Manual of Hydrology: Part 2. Low-Flow Techriques

GEOLOGICAL SURVEY WATER-SUPPLY PAPER 1542-A

Methods and practices of the Geological Survey

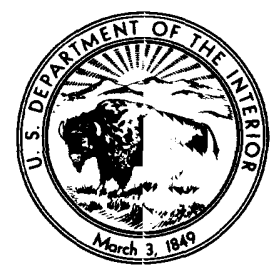




\section{UNITED STATES DEPARTMENT OF THE INTERIOR}

WALTER J. HICKEL, Secretary

GEOLOGICAL SURVEY

William T. Pecora, Director

First printing 1959

Second printing 1963

Third printing 1969 


\section{CONTENTS}

\begin{tabular}{|c|c|}
\hline & Page \\
\hline troduction & \\
\hline eparation of data..... & \\
\hline 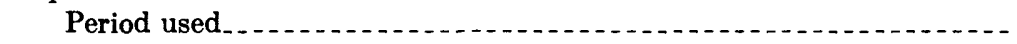 & \\
\hline 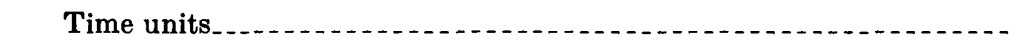 & \\
\hline 品 & \\
\hline ling flow-duration data & \\
\hline m 9-217c & \\
\hline Use of form 9-217d & \\
\hline 其 & \\
\hline ation & \\
\hline atation & \\
\hline of paper. & \\
\hline Discharge units & \\
\hline curves from short-term records & \\
\hline dex station & 4 \\
\hline ne relation & \\
\hline hort-term record & 16 \\
\hline uration curve & 17 \\
\hline of the flow-duration curve & \\
\hline of the curve & \\
\hline ( & \\
\hline 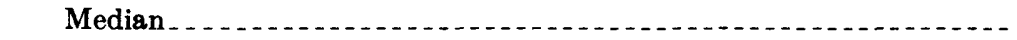 & \\
\hline ( & \\
\hline on curve & \\
\hline he effect of geology on low flows & 84 \\
\hline wer studies & 26 \\
\hline studies & 29 \\
\hline water studies. & 29 \\
\hline iabi & \\
\hline - & \\
\hline station record.- & \\
\hline nces s & \\
\hline
\end{tabular}




\section{ILLUSTRATIONS}

Figure 1. Duration curve of daily flow, Bowie Creek near Hat+iesburg, Miss., 1939-48.

Page

2. Duration curves of daily, monthly, and annual flows, Bowie Creek near Hattiesburg, Miss., 1939-48

3. Curve for changing class intervals on flow-duration $d-$ ta from Bowie Creek near Hattiesburg, Miss., 1939-48

4. Duration of daily discharge, Bowie Creek near Hattiesburg, Miss., for year ending Sept. 30, 1943, form 9-217c

5. Summary of duration of daily discharge, Bowie Crsek near Hattiesburg, Miss., 1939-48, form 9-217d

6. Comparison of flow-duration curves for three nearby stations in northeastern Georgia, water year 1952 . $A$, In terms of discharge; $B$, In terms of ratio to mean flow . . . . . . . . . . .

7. Correlation between Kankakee River and Iroquois River, based on discharge of equal percent duration.............

8. Duration curves of daily flow, Iroquois River near C'iebanse,

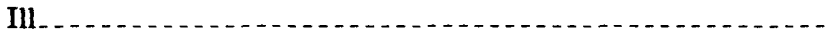

9. Correlation between Kankakee River and Iroquoi River, based on 10 discharge measurements, 1946-50 ...........

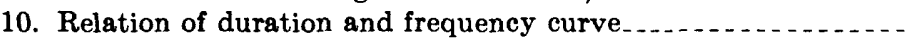

11. Geologic map of area in southern Mississippi having approximately uniform climate and altitude...........

12. Flow-duration curves for selected Mississippi streams, 1939-48_

13. Flow-duration curve applied to hydropower study

\section{TABLES}

Page

TABLE 1. Class limits for discharges on flow-duration table $\ldots . . . . . . .$.

3. Days of concurrent discharge, Kankakee River and Iroquois River stations, Ill., 1946-50 . . . . . . . . . . . . . . . . . . 


\title{
MANUAL OF HYDROLOGY: PART 2, LOW-FLOW TECHNIQUES
}

\section{FLOW-DURATION CURVES}

\author{
By J JMEs K. Searcy
}

\begin{abstract}
The flow-duration curve is a cumulative frequency curve that show the percent of time specified discharges were equaled or exceeded during a given period. It combines in one curve the fiow characteristics of a stream throu rhout the range of discharge, without regard to the sequence of occurence. It the leriod upon which the curve is based represents the long-term fiow of a st-eam, the curve may be used to predict the distribution of future flows for vaterpower, water-supply, and pollution studies.

This report shows that differences in geology affect the low-fiow ends of flowduration curves of streams in adjacent basins. Thus, duration curves ari useful in appraising the geologic characteristics of drainage basins.

A method for adjusting fiow-duration curves of short periods to represent long-term conditions is presented. The adjustment is made by correlatin " the records of a short-term station with those of a long-term station.
\end{abstract}

\section{INTRODUCTION}

Flow-duration curves have been in general use since about 1915 ; their theory has been discussed by Foster and others. (See list of references.) This chapter describes the methods used by the Geological Survey to construct flow-duration curves from streamflow data and is a revision of instructions originally prepared by W. D. Mitchell and W. B. Langbein, for use in the Survey only, and later mocified by C. H. Hardison.

The flow-duration curve (fig. 1) is a cumulative frequency curve that shows the percent of time during which specified discharges were equaled or exceeded in a given period. For example, in the period 1939-48, the daily mean flow of Bowie Creek (fig. 1) was at least 144 cubic feet per second during 90 percent of the time.

The flow-duration curve is the integral of the frequency diagram. Perhaps a simpler concept of the flow-duration curve is that it is another means of representing streamflow data combining in one curve the flow characteristics of a stream throughout the range of 


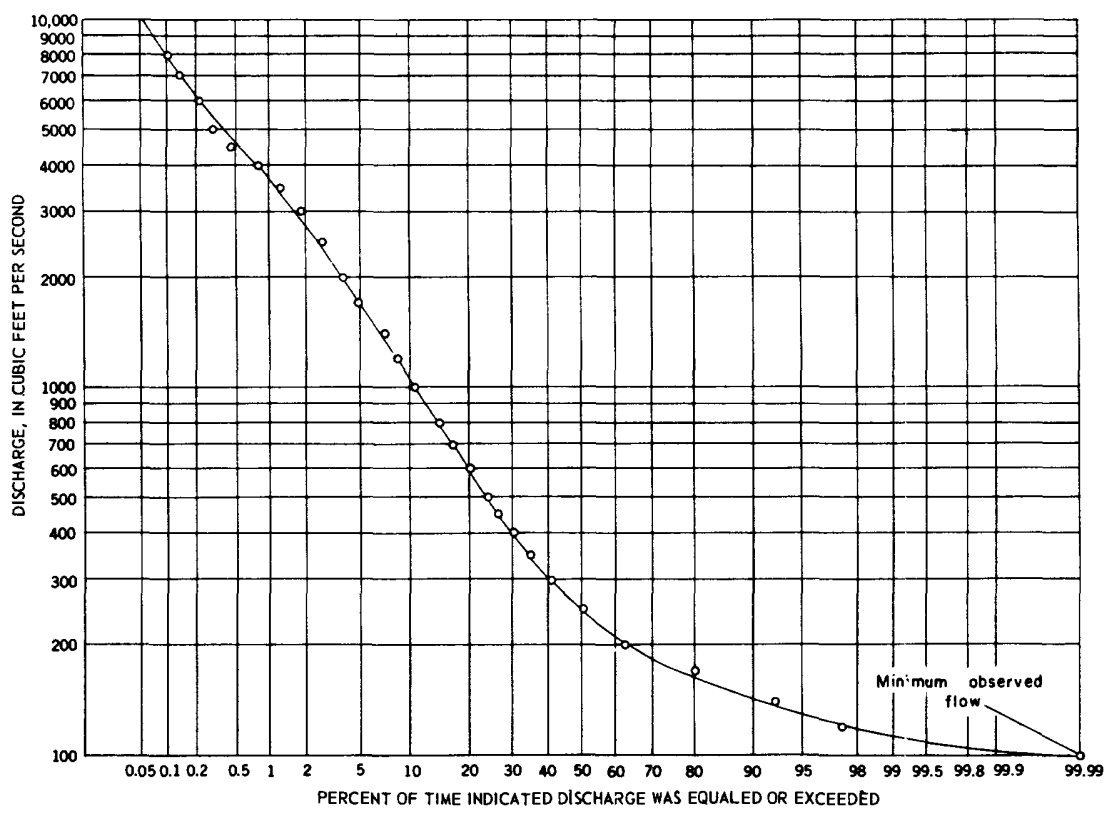

Figure 1.-Duration curve of dally flow, Bowle Creek near Hattiesburg. Miss., 1939-48.

discharge. Although the flow-duration curve does not show the chronological sequence of flows, it is useful for many studies.

To prepare a flow-duration curve, the daily, weekly, or monthly flows during a given period are arranged according to magnitude, and the percent of time during which the flow equaled or exceeded the specified values is computed. The curve, drawn to average the plotted points of specified discharges versus the percent of time during which they were equaled or exceeded, thus reprsents an average for the period considered rather than the distribution of flow within a single year.

In a strict sense, the flow-duration curve applies only to the period for which data were used to develop the curve or to the period to which the curve is adjusted. If streamflow during tha period on which the flow-duration curve is based represents the long-term flow of the stream, the curve may be considered a probability curve and used to estimate the percent of time that a specified discharge will be equaled or exceeded in the future.

The flow-duration curve provides a convenient means for studying the flow characteristics of streams and for comparing or basin with another. Various uses of the flow-duration curve are discussed later. 


\section{PREPARATION OF DATA}

The two principal methods used to construct flow-duration curves are (1) the calendar-year method (Barrows, 1943, p. 137-143; and Saville and Watson, 1933, p. 408-411) and (2) the total-period method.

In the calendar-year method, the discharges for one year are ranked according to magnitude (order number $1,2,3 * * *$ ). This process is repeated for each year of record. The discharges for each order number are averaged. A block diagram is plotted with the ab cissa in time units and the ordinate in discharge units. If a day is the time unit, the first item plotted is the average of the annual maximum days for the period of record. A percent-of-time scale can be constructed for the abscissa, if desired. The calendar-year method gives lower values for the high discharges and higher values for tha low discharges than the more accurate total-period method.

In the total-period method, all discharges are placed in class?s according to their magnitude. The totals are cumulated, beginning with the highest class, and the percentage of the totaled time is computed for each class. The data are then plotted with the discharge as the ordinate and the time in percent of total period as the abscissa.

The Geological Survey uses the total-period method and the discussion which follows is restricted to this method.

\section{PERIOD USED}

All complete years of record can be used to prepare a flow-duration curve; records for partial years should be excluded. The years for which records are complete need not be consecutive, but the records used should be for years in which physical conditions in the basin, such as artificial storage, diversions, or other manmade influ?nces, were essentially the same. The double-mass curve, which is discussed in another chapter of this manual, is useful for checking the consistency of records to be used for constructing flow-duration curves.

The data for the flow-duration curve are usually prepared on a water-year basis, the same basis as that on which the Geological Survey publishes streamflow records. The use of the water year (which ends September 30) in analyses of the flow-duration curve usually divides a low-flow period. This division is of no consequence for long records, but a flow-duration curve based on the water year of lowest, annual flow might not represent a combination of flows as low as that which actually occurred in a 12 -month period. When the flow-duration curve is used to study the variations in streamflow from year to year, yearly curves are prepared for climatic years beginning A pril 1.

In some western streams, snowmelt during a few months provides practically all the flow available for use during the year. For such 
streams, a "flow year" of a few months' length might be a more practical basis for flow-duration curves than a 12-month year.

Flow-duration curves for selected portions of a long record are used in adjusting the flow-duration curves for short re?ords to the period of the long record. Flow-duration curves for th: Geological Survey standard 25-year period, water years 1921-45, are useful for comparing streamflow in different parts of the United States; the period eventually will be changed to the 30 years $1931-60$, to conform with the practice agreed upon by the World Meteorological Organization.

When streamflow has been regulated by storage or diversions, or when the regimen varied during the period of record, a cirve for the total period has little meaning. The period used for the flow-duration curve depends on the purpose of the curve. If the curve is to be used in a hydrologic analysis of the characteristics of natural flow, only the unregulated period of record should be used. If the curve is to be used as an indication of the flow that may be expected in the future with a continuation of present conditions, only the record obtained during a period when facilities for regulation and pattern of regulation have been constant should be used. A duration curve based on the record of a short period of regulated flow and adjusted to a longer period by correlation with an unregulated stream (explained in a later section) shows the flow to be expected under the long-period hydrologic conditions, but in the pattern of regulation that existed during the short period. With the adjuster curve as a base, one can make allowances for expected additional ragulation or for changes in the pattern of regulation.

\section{TIME UNITS}

The choice of a time unit, such as the day, the week, on the month, is largely a matter of weighing the accuracy of the flow-duration curve against the work involved in its preparation. C ne primary use of such duration curves is to show the characteristics of flow. The details of the variations in flows are obscured if the time unit is long. For most streams, the monthly discharges are un satisfactory for showing the variation in flow, and duration curve of annual mean discharges would have but little use because their range in variation is comparatively small and because only a fer values are available for defining the curve.

A study in North Carolina (Foster, 1934, p. 1236) showed differences as great as 35 percent between a duration currs based on monthly mean discharges and one based on daily mean discharges. Weekly mean discharges have been used (Saville and Watson, 1933, 
p. 407) for certain relatively stable streams. Weekly means, however, are not generally available in published records, and tha advantage, if any, of using the weekly mean is offset by the additional computations required.

The effect of varying the time unit (fig. 2) is not the same for all streams. Where the flow from day to day is almost uniform, as in the St. Lawrence River, the daily and weekly duration crurves would be nearly identical, and the monthly duration curve would not differ greatly from the daily curve. On the other hand, if the stream is "flashy," with sudden floods lasting only a few hours or days, the daily and weekly curves will differ appreciably, ant the monthly curve will differ considerably from the daily curve. Daily discharges have been used almost exclusively in recent studies

After a smooth curve is drawn, the fact is often overlookec? that the mean discharge for the selected time unit was used as tho discharge that was grouped into the class intervals. Thus, if the month were chosen as the time unit, the correct statement would be that "the monthly mean discharge was at least 150 cubic feet per second for 90 percent of the months". The daily mean flows during part of the 90 percent of the time probably were less than 150 cubic fert, per

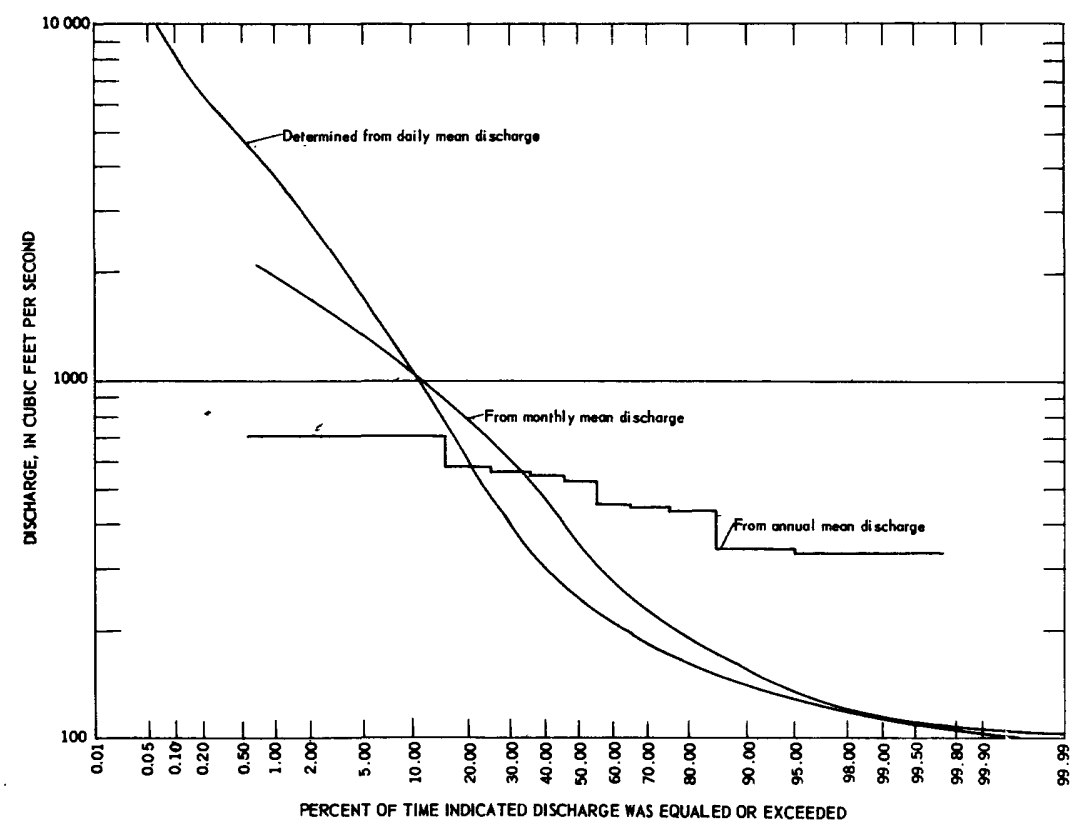

Figure 2.-Duration curves of dally, monthly, and annual flows, Bowle Creek near Hattlesburg, Miss., 1939-48. 
second. This distinction is of minor importance when the day is chosen as the time unit, unless the stream has a large diurnal fluctuation.

\section{CLASS INTERVALS}

The class intervals should provide from 20 to $30 \mathrm{we}$ ll-distributed points on the curve. The extreme points should be so selected as barely to include the extremes of daily discharge for the period of record. Table 1 shows recommended class intervals in cubic feet per second for ranges in discharge from 1 to 5 log cycles. Form 9-217c (fig. 4) gives an example of how table 1 is used for a stream whose range in discharge is almost within two log cycles. Class intervals recommended for $2 \mathrm{log}$ cycles were chosen in preference to those recommended for $3 \mathrm{log}$ cycles because the 2-cycle intervals give more points.

When flow-duration data are computed using different sets of class intervals, the data can be combined by plotting a curve of the cumulated days against the discharge for the entire period that was computed by one set of class intervals. The cumulated days for the other set of class intervals is picked from the curve. Semilogarithmic paper with a finely divided arithmetic scale is recommended for this purpose. (See fig. 3.) Discharges are plotted on the logarithmic

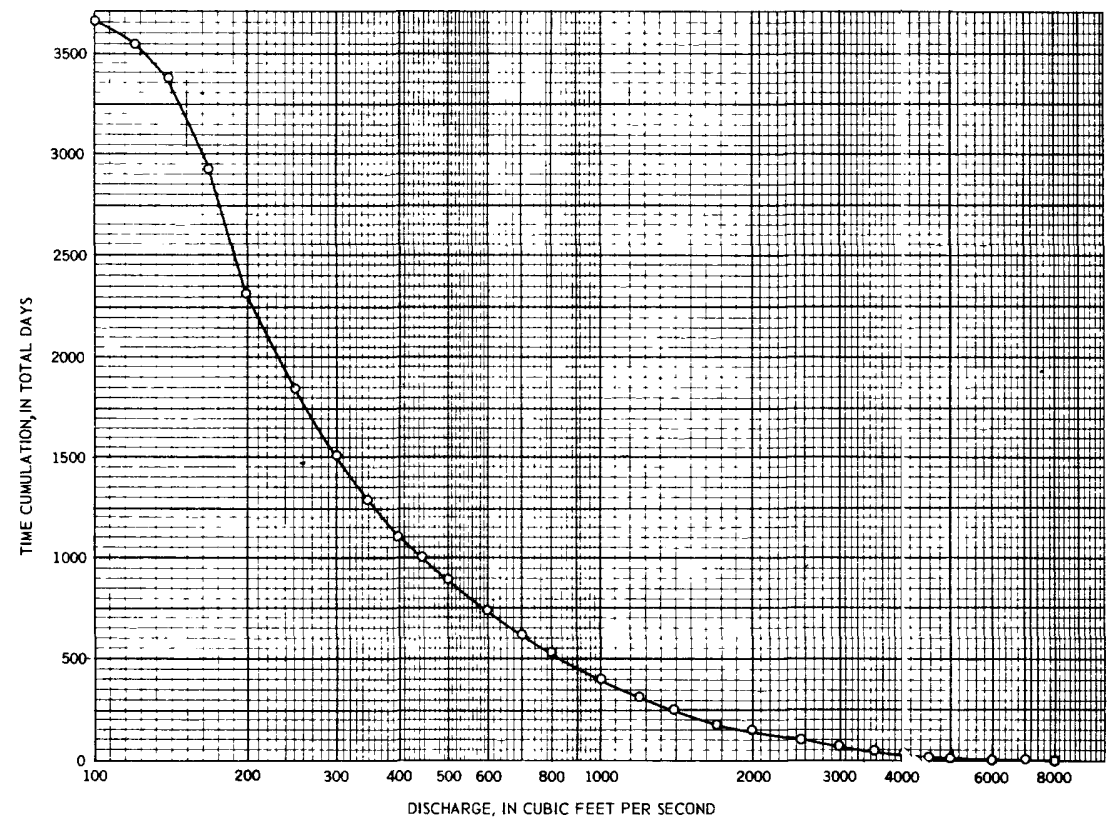

Figure 3.-Curve for changing class intervals on flow-duration data fom Bowie Creek near Hattiesburg, Miss., 1939-48. 
scale, and cumulated days are plotted on the arithmetic scale. The points are connected by straight lines. A smooth curve based on the points would be as likely to harm the results as to improve them. Data plotted in figure 3 are from figure 5.

TABLE 1.-Class limits for discharges on flow-duration table

\begin{tabular}{|c|c|c|c|c|}
\hline \multicolumn{5}{|c|}{ Range in daily discharge } \\
\hline 1 log cycle & $2 \log$ cycles & 3 log cycles & $4 \log$ cycles & 5 log cycles \\
\hline $\begin{array}{c}10 \\
11 \\
12 \\
13 \\
14 \\
15 \\
16 \\
18 \\
20 \\
22 \\
24 \\
26 \\
28 \\
30 \\
33 \\
36 \\
40 \\
45 \\
50 \\
55 \\
60 \\
65 \\
70 \\
75 \\
80 \\
90 \\
100\end{array}$ & $\begin{array}{r}10 \\
12 \\
14 \\
17 \\
20 \\
25 \\
30 \\
35 \\
40 \\
45 \\
50 \\
60 \\
70 \\
80 \\
100 \\
120 \\
\text { etc. }\end{array}$ & $\begin{array}{r}10 \\
15 \\
20 \\
25 \\
30 \\
40 \\
50 \\
60 \\
80 \\
100 \\
150 \\
\text { etc. }\end{array}$ & $\begin{array}{r}10 \\
15 \\
20 \\
30 \\
40 \\
50 \\
70 \\
100 \\
150 \\
\text { etc. }\end{array}$ & $\begin{array}{r}10 \\
15 \\
20 \\
30 \\
50 \\
70 \\
100 \\
150 \\
\text { etc. }\end{array}$ \\
\hline
\end{tabular}

Nore-Table shows sequence of numbers for five ranges in discharge. Locate decimal point and starting discharge to suit conditions. In general, use cycle closest to observed range. Where considerable data have been tabulated at a station by using other rules for class intervals, additional data would normally be tabulated by using the class intervals previously used.

\section{COMPILING FLOW-DURATION DATA}

A digital computer or a similar machine can be used to compile the flow-duration data. The machine furnishes the same kinds of data as are shown in figure 5, including the data in columns haaded "total," "total days," and "percent of time." If a machine is not available, the method shown in figures 4 and 5 is recommended for compiling the flow-duration data.

\section{USE OF FORM 9-817C}

Form 9-217c, shown in figure 4, is designed for arranging the daily flows during 1 water year, in classes according to magnitude. The lower limit of each class interval (from table 1) is tabulated in the discharge column.

For the daily 'discharge of each day of gaging-station record, a tally mark is made in the appropriate monthly column on the line 
representing the highest flow that the flow of the particular day equals or exceeds. The tally marks for each month are counted to ensure that one tally mark was made for each day of the month. The tally marks in each class are counted and the number is entered in

Puly

UNITED STATES DEPARTMENT OF THE INTERIOR

GEOLOGICAL SURVEY

ribo

Duration table of ...dafly discharge, Bowfe Creek_near Eatt1esburg, Miss.

for tho year endlag Sept. so, 1943

Drainage aroe, .........304t_............ meare millow

\begin{tabular}{|c|c|c|c|c|c|c|c|c|c|c|c|c|c|c|c|c|}
\hline \multicolumn{2}{|c|}{ DIBCHARGE } & \multicolumn{13}{|c|}{ 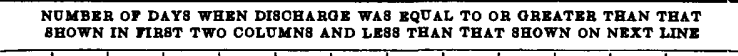 } & & \\
\hline & ch & oct. & Nor. & Dea. & Jan. & pob. & Mar. & Apr. & May & Jume & July & Ans. & Bept. & Year & & \\
\hline & 100 & & & & & & & & & & & & & & & \\
\hline & 120 & 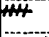 & & & & & & & & & & & & 5 & & \\
\hline & 140 & -1" & & & & & & & & & ii & & 7 & 40 & & \\
\hline & 170 & 2 & & iii & & & & & & & 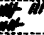 & int & wit & 85 & & \\
\hline & 200 & & & 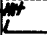 & & & & & & & & & $f$ & 49 & & \\
\hline & 250 & & & in & 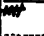 & Wu & 1 & 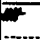 & $m$ & & T... & & $\pi$ & 30 & & \\
\hline & 300 & & ii & $i$ & $\ldots$ & $i$ & & 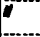 & $i$ & & & & & 17 & & \\
\hline & 350 & & 1 & 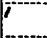 & it & aii & 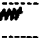 & $7 i$ & ii & & & & $i$ & 21 & & \\
\hline & 400 & & 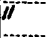 & $\vec{i}$ & $m$ & $\pi$ & $i$ & 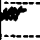 & 1 & & & & & 16 & & \\
\hline & 450 & & & ini & 37 & $i$ & 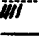 & & & & 7 & & i & 16 & & \\
\hline & 500 & 1 & & al & 1 & $t$ & 7 & $B I$ & 1 & & & & 1 & 12 & & \\
\hline & 600 & & & 1 & $j^{-1}$ & & $\bar{z}$ & $a$ & & & & & 1 & 10 & & \\
\hline & 700 & 7 & & 1 & & 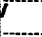 & $\bar{\ldots}$ & 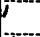 & & & if & & & 7 & & \\
\hline & 800 & $i$ & 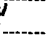 & & tail & & $i$ & ii & & & & & in & 14 & & \\
\hline & 1,000 & 1 & & "i & & 1 & iti & $\ddot{\mu}$ & & & I & & $\pi$ & 12 & & \\
\hline & 1,200 & & & i & 1 & & it & $T$ & & & & & & 5 & & \\
\hline & 1,400 & 1 & & $i$ & 7 & & & $i$ & & & & & $i$ & 5 & & \\
\hline & 1,700 & & & & & it & 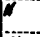 & 1 & & & & & & 5 & & \\
\hline & 2,000 & 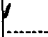 & & & & & in & & & & & & & 4 & & \\
\hline & 2,500 & & & 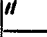 & & & 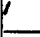 & $i$ & & & & & & 4 & & \\
\hline & 3,000 & & & & & & & & & & & & & & & \\
\hline & 3,500 & & & 1 & & & & & & & & & & 1 & & \\
\hline & 4,000 & & & & & & i & 1 & & & & & & 2 & & \\
\hline & 4,500 & & & & & i & $t$ & & & & & & & 2. & & \\
\hline & 5,000 & & & & & 1 & & & & & & & & 1 & & \\
\hline & 6,000 & & & & & & & & & & & & & & & \\
\hline & 7,000 & & & & & & & & & & & & & & & \\
\hline & 8,000 & & & & & & & & & & & & & & & \\
\hline & 10,000 & & & & & & i & & & & & & & $\ldots$ & & \\
\hline & 12,000 & & & & & & & & & & & & & & & \\
\hline & 14,000 & & & & & & $\sqrt{1}$ & & & & & & & 1 & & \\
\hline & 17,000 & & & & & & & & & & & & & & & \\
\hline & & & & & & & & & & & & & & & & \\
\hline & & & & & & & & & & & & & & & & \\
\hline & & 31 & 30 & 31 & $|3|$ & 28 & 3.1 & 30 & 31 & 30 & 31 & 31 & 30 & 365 & & \\
\hline
\end{tabular}

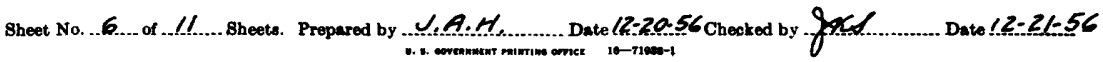

Frougr 4.-Duration of dally discharge, Bowie Creek near Hattlesburg. Mlgs., for year ending Sept. 30, 1943, form 9-217c. 
the column for the year. The total of the yearly column should equal the number of days in the year.

An alternate method of compiling form 9-217c is to go through a month, counting the days in each class and showing the count by a numeral instead of several tally marks. A check mark is placed by each day when it is counted; this reduces the number of items to be scanned for successive class intervals.

\section{USE OF FORM 9-817D}

The yearly totals, by classes, are transferred from the yearly forms (fig. 4) to the summary form (fig. 5), by using a column for each year. Column headings, "total," "total days," and "percent of time," are added at the end of the yearly totals, and the period to which the totals apply is indicated. Class totals are cumulated from the bottom upward, and the percent of the total number of days is computed for each class summation and entered in the percent-of-time column. The columns "total days" and "percent of time" reprasent the time that the discharge shown in column 2 was equaled or exceeded. Column 1 is reserved for listing the equivalent of column 2 in other units, such as cubic feet per second per square mile, million gallons per day, or ratio to mean discharge.

When additional years of record become available, the total days in each class interval for those years can be added to the existing summary table to obtain a total for the entire period.

\section{PRESENTATION OF DATA}

The results of a flow-duration study may be presented in tal rlar or in graphical form. The tabular presentation has the advartage of being more compact than the graphical presentation, but it is somewhat less clear.

In either form of presentation, the title should show the time interval (such as "daily flow"), the name of the gaging station, and the period represented by the data.

\section{TABULAR PRESENTATION}

Tabular arrangements of flow-duration data may show either the discharge for a given percent of duration or the percent of tims for a given discharge. An arrangement showing the discharge corresponding to given percents of duration is better suited to hydrologic comparisons than is an arrangement showing the percent of time for a given discharge.

Some compilations of flow-duration data show the yearly class totals as shown in figure 5; others show skeleton tables with only enough points given to define a duration curve. 


\section{GRAPHICAL PRESENTATION}

The curve in figure 1 shows the duration of daily flow of Bowie Creek near Hattiesburg for the water years 1939-48. The abscissa should be labeled as shown in this figure, rather than just "percent

Jaly 1006

UNITED STATES DEPARTMENT OF THE INTERIOR

GEOLOGICAL BURVEY
WATER REIOUNCIS DIVIEON

File.

Duration table aummary of daily discherge, Bowle Creek near Hatt1esburg, Miss.

\begin{tabular}{|c|c|c|c|c|c|c|c|c|c|c|c|c|c|c|}
\hline$\frac{\text { for the years ..... I }}{\text { Drscharox }}$ & \multicolumn{14}{|c|}{$\begin{array}{l}\text { NUMBER OF DAYS WHEN DIBCHARGE WAS EQUAL TO OR GREATER TBAN THAT } \\
\text { GHOWN IN YIRST TWO COLUMNS AND LEGS TEAN THAT SBOWN ON NEXT LINE } \\
\end{array}$} \\
\hline Cls & 1939 & 1940 & 1941 & 1942 & 1943 & 1944 & 1945 & 1946 & 1947 & 1948 & $\mid \begin{array}{l}\text { Total } \\
39-48\end{array}$ & $\begin{array}{r}\text { Total } \\
\text { days }\end{array}$ & $\begin{array}{l}\text { Perce } \\
\text { of } t\end{array}$ & ne \\
\hline 100 & 61 & 17 & & 17 & & & & & & & 95 & 3653 & 100 & \\
\hline 120 & 68 & 64 & 10 & 23 & 5 & 3 & & & & & 17.3 & 35.58 & 97 & 4 \\
\hline 140 & 50 & 65 & 61 & 57 & 40 & 56 & 60 & 24 & 29 & 12 & 454 & 3585 & 92 & 7 \\
\hline 170 & 27 & 47 & 75 & 48 & 85 & 53 & 46 & 70 & 8. & 99 & 631 & 2.931 & 80. & 2 \\
\hline 200 & 46 & 50 & 42 & 57 & 49 & 41 & 38 & 50 & 29 & 52 & 454 & 2300 & 63. & 0 \\
\hline 250 & 18 & 16 & 53 & 41 & 30 & 26 & 47 & 2.2 & 34 & 45 & 337 & 1846 & 50 & 5 \\
\hline 300 & 10 & 9 & 32 & 14 & 17 & 1.6 & 31 & 27 & 3.1 & 23 & 210 & 1509 & $4 \%$ & 3 \\
\hline 350 & 9 & 14 & 18. & 16 & 21 & 26 & 24 & 20 & 16 & 17 & 181 & 1299 & 35. & 6 \\
\hline 400 & 4 & 5 & 13 & 10 & 16 & 16 & 10 & 21 & 13 & 13 & 121 & 1118 & 30 & 6 \\
\hline 450 & 11 & 6 & 9 & 13 & 16 & 15 & 15 & 13 & 5 & 10 & 113 & 997 & 27. & 3 \\
\hline 500 & 10 & 11 & 8 & 11 & 12 & 18 & 20 & 20 & 12 & 20 & 142 & 884 & 24. & 2 \\
\hline 600 & 10 & 7. & 9 & 10 & 10 & .15 & 19 & 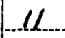 & 20 & 15 & 126 & Z62 & 20. & 3 \\
\hline 700 & 4 & 3 & 7 & 4 & 7 & 16 & 14 & 14 & 14 & 6 & 89 & 616 & 16. & 9 \\
\hline 800 & 12 & 15 & 6 & 12 & 14 & 18 & 10 & 19 & 13 & 12 & 131 & .527 & 14 & 4 \\
\hline 1,000 & 7 & 3 & 5 & 3 & 12 & 12 & 10 & 13 & $\mu$ & 2 & 83 & 396 & 10. & 8 \\
\hline 1,200 & 4 & 3 & 3 & 5 & 5 & 3 & 5 & 13 & 9 & 5 & 55 & 313 & 8. & 57 \\
\hline 1,400 & 6 & 12 & 2 & 7 & 5 & 13 & 4 & 11 & 9 & 9 & 78 & .258 & 7. & OK \\
\hline 1,700 & 3 & 4 & 3 & 4 & 5 & 1 & 3 & 2. & 10 & 4 & 39 & 180 & 4. & 93 \\
\hline 2,000 & 2 & 5 & 1 & 3 & 4 & 5 & 5 & 3. & 7 & 5 & 40 & 141 & 3. & 86 \\
\hline 2,500 & 1 & 2 & 6 & 2 & 4 & 5 & 3 & 1 & 7 & 3 & 34 & 101 & 2. & 26 \\
\hline 3,000 & 2 & 4 & & 4 & & 3 & & 3 & 4 & 1 & 21 & 67 & 6 & 83 \\
\hline 3,500 & & 2 & & 2 & 1 & 3 & 1 & 2 & 3 & 2 & 16 & 46 & & 26 \\
\hline 4,000 & & 2 & & & 2 & 2 & & $\ell$ & 4 & 2 & 13 & 30 & & 821 \\
\hline 4,500 & & & & 1 & 2 & & & & 2 & 1 & 6 & 17 & & 465 \\
\hline 5,000 & & & 1 & & 1 & & & & & 1 & 3 & 11 & & 301 \\
\hline 6,000 & & & 1 & & & & & & & 2 & 3 & 8 & & 219 \\
\hline 7,000 & & & & 1 & & & & & & & 1 & 5 & & 137 \\
\hline 8,000 & & & & & & & & & 2 & & 2 & 4 & & 109. \\
\hline 10,000 & & & & & $\ldots$ & & & & & & 1 & 2 & & 0.55 \\
\hline 12,000 & & & & & & & & & & & & & & \\
\hline 14,000 & & & & & 1 & & & & & & 1 & 1 & & 027 \\
\hline 17,000 & & & & & & & & & & & & & & \\
\hline & & & & & & & & & & & & & & \\
\hline & & & & & & & & & & & & & & \\
\hline & 365 & 366 & 365 & 365 & 365 & 366 & 36.5 & 365 & 365 & 366 & 3653 & & & \\
\hline
\end{tabular}

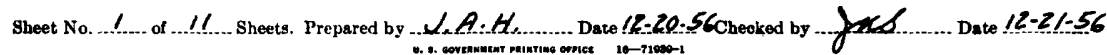

Flgura 5.-Summary of duration of dally discharge, Bowie Creek near Hattiesburg, Miss., $1939-48$, form $9-217 d$. 
of time." When the curve represents basic data for the period of record, as in this figure, plotted points are shown and a smootr curve is drawn by eye to fit the data. When the duration data have been adjusted to represent a longer period, a smooth curve alone is sufficient. If the curve is merely one step in a hydrologic analysis, straight lines between successive points are preferable because they prevent introduction of differences due to personal judgment.

\section{TYPE OF PAPER}

Flow-duration curves are plotted on rectangular-coordinate paper, logarithmic paper, arithmetic-probability paper, or logarithmicprobability paper. For general use the logarithmic-probability paper is recommended.

The advantage of using a logarithmic scale for the discharge (ordinate) is apparent when it is noted that normally 3 or 4 log cycles are required for the range in discharge. An arithmetic scale that would accommodate the range in discharge of most streams would be undesirably small for all except the highest discharges.

An arithmetic scale for the percent of time is considered easier to use, but such a scale provides poor definition at the extremities, where the slope of the flow-duration curve changes rapidly. Because of the difficulty of determining the area under a curve flotted on a logarithmic-probability paper, the rectangular coordinates are often used in hydroelectric-power studies and similar studies.

A logarithmic scale for the percent of time expands one end of the curve but undesirably condenses the other end.

The probability scale expands both ends of the flow-duration curve. Data that are normally distributed plot as a straight line on probability paper. As the logarithms of discharge are more normally distributed than the discharge itself, the logarithmic-probsbility paper tends to straighten out the flow-duration curve.

\section{DISCHARGE UNITS}

For tabulating flow-duration data, to express discharge in cubic feet per second is most convenient because the daily dischargss are published in those units. But the discharge data can be converted to any other desired unit for plotting the flow-duration curve. For example, if the duration curve is to be used for a study of flow at the gaging-station site, the ordinate can be in cubic feet per second, in million gallons per day, or in some function of discharge--such as kilowatts corresponding to the net head and plant efficiency-available at the site. If the duration curve is to be used for comraring flow characteristics among streams, to express discharge in cubic 
feet per second per square mile or in ratio to average flow is suitable for the ordinate scale.

To express discharge either in cubic feet per second per square mile or in ratio to mean flow eliminates the effect of size of drainage area; but to express discharge in ratio to mean flow eliminates also the effect of differences in mean annual runoff per square mile. For many streams, comparisons based on cubic feet per second per square mile are almost identical with comparisons based on ratio to mean flow. However, among stream basins in which $\mathrm{p}$ recipitation differs greatly, flow-duration curves based on ratio to mean flow are much closer together than those based on cubic feet per second per square mile. For example, in figure 6, flow-duration curves for three nearby stations in northeastern Georgia are shown for the water year 1952. Figure $6 \mathrm{~A}$ shows the flow-duration curves in cubic feet per second per square mile, and figure $6 B$ shows the same flowduration curves in ratio to mean flow. No attempt was made to determine the average precipitation in each drainage basin, but the precipitation total for the water year 1952 is given for one precipitation station in each drainage basin.

Discharge per square mile and ratio to mean annual flow are useful conversions for hydrologic comparisons, but care should 1 . taken not to imply that the stream with the highest yield per square mile is the best source of supply regardless of the size of its drrinage area, or that the flow varies uniformly over the drainage basin.

\section{LONG-TERM FLOW-DURATION CURVES FROM SHORT- TERM RECORDS}

Very seldom do all the gaging-station records in a given area cover concurrent periods. If records are to be compared with each other, they must represent, or be adjusted to, concurrent periods, in order that differences between the records will be due to differ?nces in climatic or drainage-basin characteristics and not to the fact that the records cover different periods of time. Furthermore, flow-duration curves based on short records are unreliable for predicting the future pattern of flow, but they can be made reliable by adjusting them to represent longer periods.

Several methods (Mitchell, 1950, p. 12-18) are available for adjusting short-term records to long-term records. In the method now used by the Geological Survey (sometimes called the index-station method), a relation is established between two stations for the short period of concurrent record by plotting a graph of the discharges for given duration points at one station against the corresponding discharges at the other station. The graph for the short period is also 

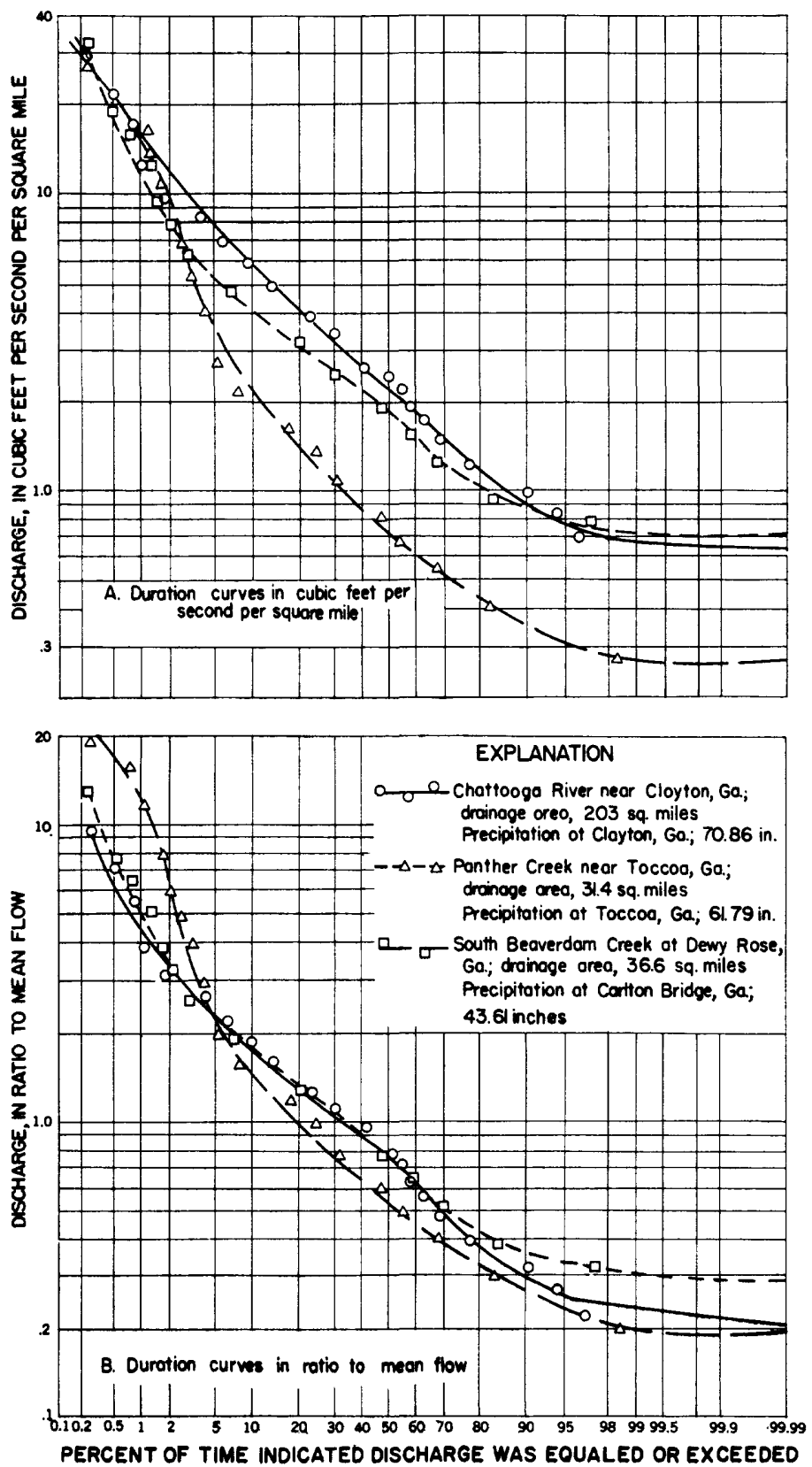

Figorn 6. - Comparison of flow-duration curves for three nearby stations in north ?astern Georgla, water year 1852 . 
assumed to represent the relation between the stations for a long period. If the assumption is true, the flow available $5 ?$ percent of the time at the long-term station can be used to enter the curve of relation (based on the short period of record), in ordor to obtain the adjusted (to long term) flow available 50 percent of the time at the short-term station. Adjusted flows for other percents of time at the short-term station can be obtained in the same manner.

\section{SELECTION OF THE INDEX STATION}

In order for the index-station method to be valid, both the index station and the short-term stations must be influenced by similar climatic occurrences. Although the drainage basins of these stations need not have concurrent rains, each basin should have t] 1 s same likelihood of receiving rain. Thus, a station in the rain shadow of a mountain could hardly be used to adjust the records of a stream on the opposite side of the mountain.

The index station used to adjust the record for a short-term station should be carefully selected. A gaging station whose record has previously been used in a regional low-flow analysis usually serves as a good index station. A station on the same stream $\varepsilon s$ the shortterm station is usually a better index station than one or a stream in an adjacent basin. The index station and the short-term station must have a sufficient period of concurrent records to establish a usable relation. Distance from other stations is a factor in selecting the index station. Records from gaging stations nearby, other factors being equal, provide better relations than records from remote stations, but usable relations have been established between stations as far apart as 50 miles, when long periods of concurrent record were available on which to establish the relation.

\section{ESTABLISHING THE RELATION}

A flow-duration curve is prepared for the short-term record (fig. 8 ), and a flow-duration curve for the corresponding poriod is prepared for the long-term record. The points are connected by straight lines rather than by a smooth curve, in order not to introduce personal interpretation of the data.

The discharges for about 15 percent-duration points, $\mathbf{r}^{\wedge}$ nging from 0.5 to 99.5 percent (table 2), at the short-term station are plotted on logarithmic paper against the discharges for the srme percentduration points at the long-term station. A percent-duration point is the point on the flow-duration curve that corresponds to a specified percent of time. 
A straight line or lines (connected by a transition curve at sharp breaks) are drawn through the plotted points, with the following suggestions serving as guides:

1. Straight lines or a smooth curve should be drawn in preference to a wavering line connecting all points.

2. On logarithmic paper, the upper end of the curve of re'ation is often a 45-degree line and is usually on the drainage-area ratio (equal-yield) line or parallel to it. If the two st"eams differ in their high-flow characteristics, the upper end of the curve of relation will depart from a 45-degree line.

3. If the geologic characteristics of the basins differ, the lower points will define a relation other than a 45-degree lin?.

TABLE 2.-Discharge of equal percent duration on two rivers in Illincis

\begin{tabular}{|c|c|c|c|c|}
\hline \multicolumn{5}{|c|}{ Discharge, in cubic feet per second } \\
\hline Percent duration & $\begin{array}{c}\text { Kankakee } \\
\text { River at } \\
\text { Momence } \\
\text { 1946-50 }\end{array}$ & $\begin{array}{c}\text { Iroquois River } \\
\text { near Chebanse } \\
\text { 1946-50 }\end{array}$ & $\begin{array}{c}\text { Kankakee } \\
\text { River at } \\
\text { Momence } \\
\text { 1924-50 }\end{array}$ & $\begin{array}{l}\text { Iroquo;a River } \\
\text { near C'iebsnse, } \\
\text { adjusted to } \\
1920^{-}-50\end{array}$ \\
\hline $\begin{array}{l}90 \\
90 \\
90\end{array} 80$ & $\begin{array}{r}542 \\
558 \\
566 \\
618 \\
700 \\
882 \\
1,080 \\
1,280 \\
1,580 \\
1,930 \\
2,500 \\
3,440 \\
4,640 \\
5,200 \\
6,380 \\
7,180 \\
8,000\end{array}$ & $\begin{array}{r}46 \\
49 \\
53 \\
67 \\
102 \\
188 \\
334 \\
525 \\
750 \\
1,150 \\
1,990 \\
3,220 \\
5,300 \\
7,160 \\
9,700 \\
12,300 \\
14,600\end{array}$ & $\begin{array}{r}432 \\
453 \\
508 \\
578 \\
658 \\
822 \\
970 \\
1,130 \\
1,370 \\
1,680 \\
2,100 \\
2,770 \\
3,940 \\
4,800 \\
5,780 \\
6,600 \\
7,210\end{array}$ & $\begin{array}{r}23 \\
26.5 \\
37.8 \\
54 \\
80 \\
150 \\
240 \\
380 \\
580 \\
880 \\
1,320 \\
2,130 \\
4,000 \\
5,780 \\
7,800 \\
10,300 \\
12,100\end{array}$ \\
\hline
\end{tabular}

4. Little weight should be given to the points at the extreme upper or lower end when the line is drawn. Comparison of curves of relation based on successive 5-year periods shows th at an apparent sharp break in the relation near the extrenes is likely to be balanced by a break in the opposite dircetion during the next 5-year period.

To demonstrate the method, records from two stream-gaging stations in northeastern Illinois are used. The Iroquois River near Chebanse (record for water years 1924-50) is used as the short-term station with the assumption that its record covers only the water years 1946-50. The record for the index station Kankakee Rirer at Momence (record for water years 1916-50) is assumed to cover only the period 1924-50, so that the extension of the short-term station record may be compared with the actual record. 
The flow-duration curve for 1946-50 at Kankakee River at Momence is not shown, but table 2 gives the discharge for equal parcent duration picked from the curve.

The curve of relation in figure 7 is plotted from the data in the second and third columns of table 2 .

\section{ADJUSTING THE SHORT-TERM RECORD}

The discharges for various percent-duration points at the long-term station (col. 4, table 2) are used as the argument in the curve of rela-

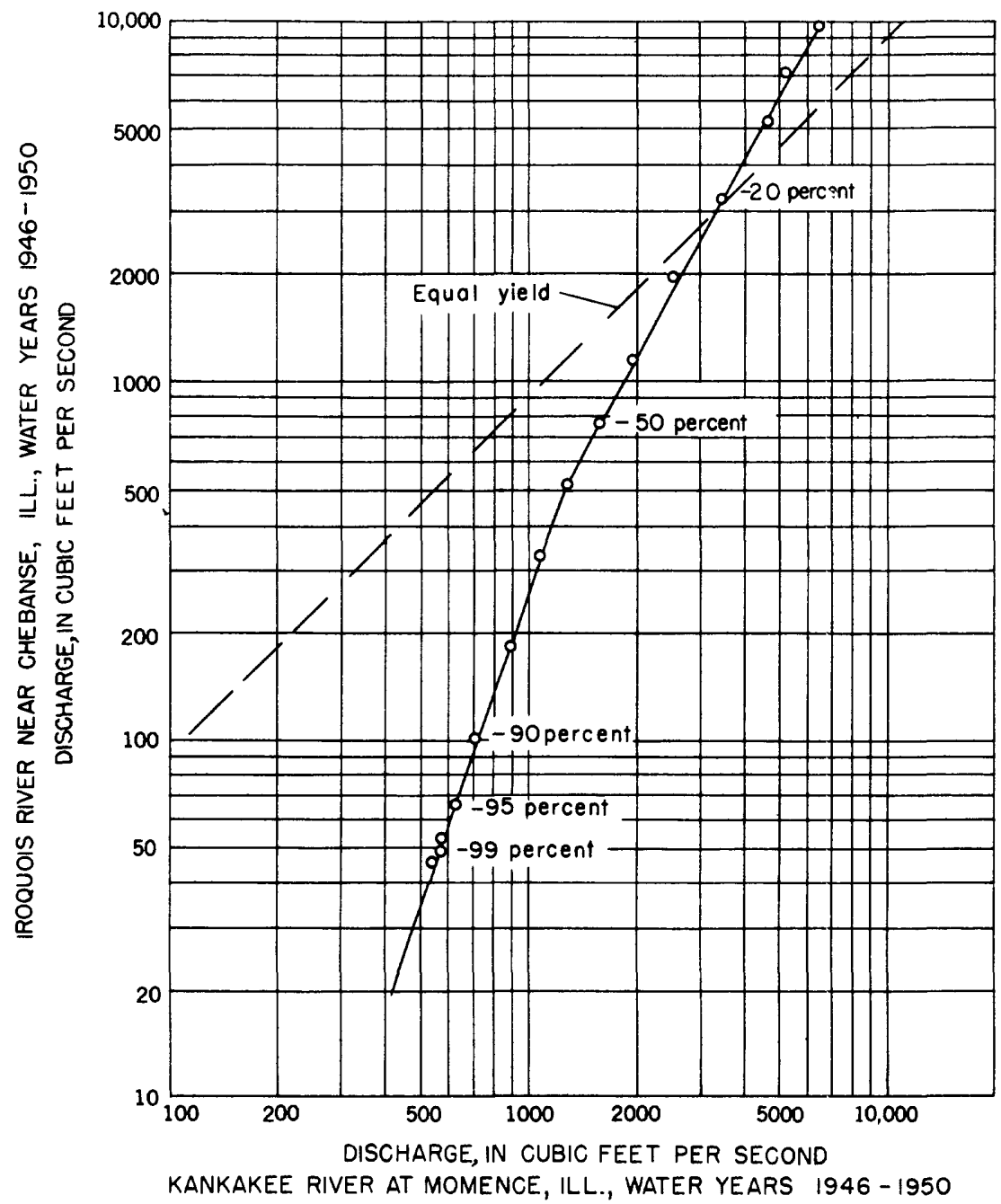

Figurs 7.-Correlation between Kankakee RIver and Iroquols River, basec on discharge of equal percent duration. 
tion (fig. 7) to obtain the adjusted discharge at the short-term station for the particular percent-duration point. For example, the discharge of the Kankakee River (long period, 1924-50) at the 50-percent-duration point is $1,370 \mathrm{cfs}$. Entering 1,370 cfs, on figure 7, we find that the discharge (adjusted to the long period, 1924-50) of Iroquois River at the 50-percent duration point is $580 \mathrm{cfs}$. The discharge for other percent-duration points is obtained in the same way, and the adjusted values are plotted to define the adjusted curve (fig. 8 ).

Figure 8 shows the actual flow-duration curve for the short period (1946-50) and the flow-duration curve adjusted to the long period (1924-50). For comparison, the curve for the long period (19?4-50) based on actual record is shown also. The flow-duration curve adjusted to the long period compares favorably with the actual longperiod record.

\section{ESTIMATION OF THE FLOW-DURATION CURVE}

Frequently there is need for flow-duration data on streams for which there are no gaging-station records. When the low-flow end of the duration curve is of prime interest, estimates based on runoff per square mile of nearby gaged areas are seldom reliable unless it is known that the ground-water geology of the two areas is the same.

The effect of basin geology on streamflow can be evaluated by several discharge measurements made during periods of base flow. The discharge measurements at the base-flow observation point should preferably be made over a period of several years, but, regarcless of when they are made, estimates of low flow based on base-flow masurements are much more reliable than those based on the runoff per square mile of nearby gaged areas.

The use of base-flow measurements for estimating a flow-duration curve is explained by an example for which the Kankakee River and Iroquois River stations are used. In this example we assume that the Iroquois River near Chebanse is ungaged, but that 10 base-flow measurements have been made. The Kankakee River at Momence is used as the index station.

Concurrent daily discharges for two days each year during the period 1946-50 are used as discharge measurements. (See table 3.) The selected days are days of base-flow periods when little change in discharge occurred at either station. The same base-flow criteria would be followed when discharge measurements are made on ungaged areas, except that the rate of change in discharge could be observed only at the gaging station. Local inquiry will usually reveal the time of the last rain on the ungaged area. 


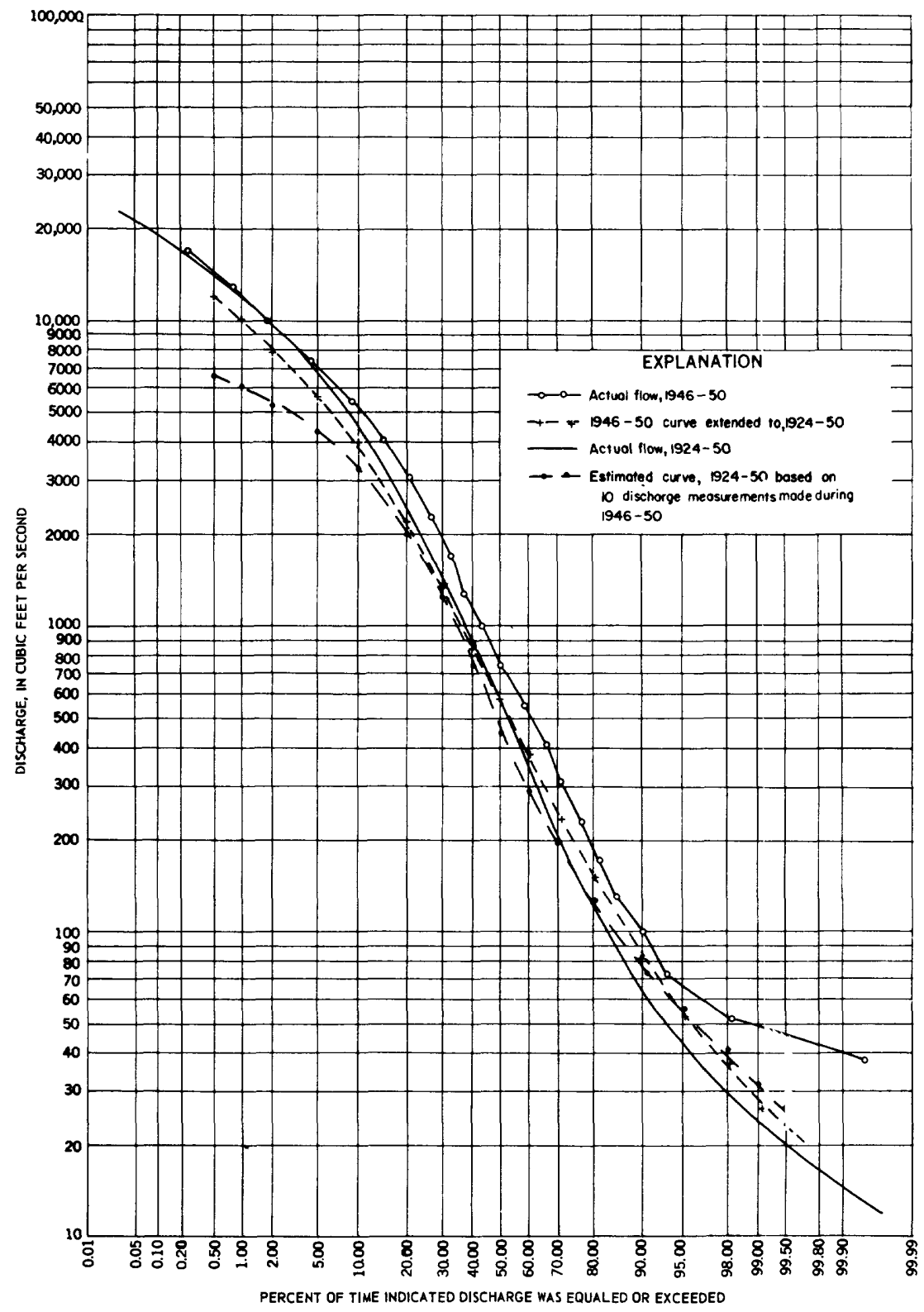

Figure 8.-Duration curves of dally flow, Iroquols River near Chełanse, III. 
TABLE 3.-Days of concurrent discharge, Kankakee River and Iroquois River Stations, Ill., $1946-50$

\begin{tabular}{c|r|r}
\hline & \multicolumn{2}{|c}{$\begin{array}{c}\text { Discharge, in cublc feet } \\
\text { per socond }\end{array}$} \\
\cline { 2 - 3 } Date & $\begin{array}{c}\text { Kankakee } \\
\text { River at } \\
\text { Momence, nl. }\end{array}$ & $\begin{array}{c}\text { Iroquois } \\
\text { River at } \\
\text { Chebanse, Ill. }\end{array}$ \\
\hline Aug. 31, 1946 & 600 & 56 \\
Sept. 20,1946 & 525 & 48 \\
July 16, 1947 & 1,280 & 306 \\
Aug. 24, 1947 & 783 \\
Aug. 26, 1948 & 682 & 107 \\
Sept. 28, 1948 & 562 & 61 \\
Sept. 1, 1949 & 712 & 107 \\
Sept. 25, 1949 & 630 & 63 \\
Jan. 1, 1950 & 4,460 & 4,880 \\
Sept. 1, 1950 & 1,040 & 168 \\
\hline
\end{tabular}

The base-flow measurements (days of concurrent dischargo) are plotted on figure 9 to establish a relation between the ungagad site (Iroquois River near Chebanse) and the index station (Kankakee River at Momence). It is obvious that the measurements group near the lower end of the curve of relation and that lines of various slopes could be drawn to average the group of measurements. Thus, the measurements serve to fix the location of a line of relation lut not its slope.

The characteristics of relations between gaging-station records furnish a basis for drawing the curve of relation when only the fosition of the curve at its lower end is known. An equal-yield line (drainage-area ratio), drawn as a 45 -degree line on logarithmic paper through the plot of the drainage areas, serves as a convenient guide for this purpose. Although the curve of relation diverges from the equal-yield line at low flow, for many streams it tends to become parallel to the equal-yield line at higher flows, because, at high flow, storm runoff predominates and the base flow, affected by geology, is a negligible part of the total flow. However, when one basin contains enough storage, either on the surface or in the ground, to distribute the effect of storm precipitation over several time units, and tha other basin contains comparatively little storage, the upper end of the line of relation deviates from the equal-yield line toward the station with less storage. (See fig. 7.)

For many streams in the eastern part of the country, a line through the base-flow measurements intersects the equal-yield line at a discharge about $11 / 2$ times that of the mean discharge. The actual point of intersection is fairly stable for a given area and should preferably be located by correlating several gaging-station records. The point of intersection of the equal-yield line and low-flow line is used as a pivot point to draw a line through the average of the low-flor meas- 
urements. In figure 9 , a discharge $11 / 2$ times the averace discharge for the 1924-50 period at Momence was used as the pivot point. The relation based on low-flow measurements can be used to estimate a flow-duration curve in the same way that figure 7 was us ?d to extend a flow-duration curve.

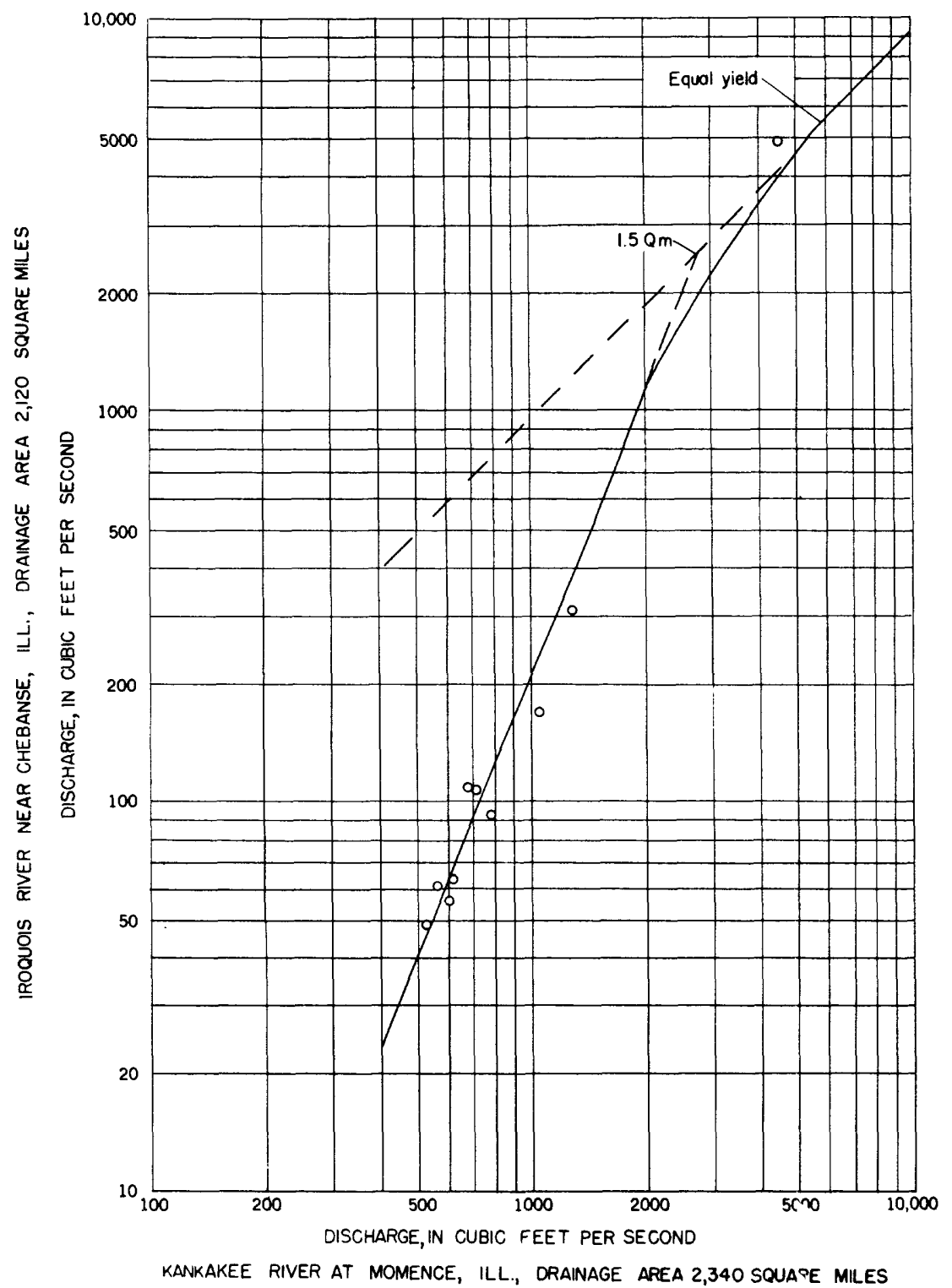

Figura 9.-Correlation between Kankakee River and Iroquois River, based on 10 dicharge measurements, 1946-50. 
In the example, index-station discharges for the 17 percent-duration points in column 4 of table 2 are used as the argument in figur 9 to obtain discharges for the corresponding percent-duration points at the ungaged site. The data thus obtained are plotted on figur? 8 so that the estimated flow-duration curve might be compared with the duration curve based on actual record. Although in the example the duration curve is estimated throughout its range, reports published by the Geological Survey usually show only the lower half of the curve, because the relation at higher flows may not follow the equalyield line. It will be seen in figure 7 that the upper line of relation between the stations used in the example actually crosses the equalyield line. The result of assuming an equal-yield relation is seen on figure 8 by the departure of the estimated curve below 10 percent of the time.

The line of relation should not be extended to flows much lower than those measured at the ungaged site unless one has a thorough knowledge of the geology of the two drainage basins. Some lines of relation have a second break at an extremely low flow, particularly when one stream goes dry and the other is perennial.

\section{HYDROLOGIC SIGNIFICANCE OF THE FLOW-DUPA- TION CURVE}

The water measured at a gaging station is the surface outflow of the drainage basin above a specified point on the stream. Thus, the streamflow record integrates the effects of climate, topography, and geology, and gives a distribution of runoff both in time and in magnitude. When the flows are arranged according to frequency of occurrence and a flow-duration curve is plotted, the resulting curve shows the integrated effect of the various factors that affect runoff.

It is important to keep in mind that the flow-duration curve is an average curve for the period upon which it is based. To say that a flow-duration curve based on a 15-year record represents the dis'ribution of the yearly flow is incorrect. The flow lower than that which was equaled or exceeded 96.7 percent of the time might have occurred during one 6-month period of a 15-year drought. Such a flow would not be expected, on the average, 3.3 percent of the time each year, but would be expected, on the average, 50 percent of the time during one year of each 15-year period. The flow-duration curve for the roriod is often supplemented by flow-duration curves for the year of lowest runoff and the year of maximum runoff. 


\section{SHAPE OF CURVE}

As the shape of the flow-duration curve is determined by the hydrologic and geologic characteristics of the drainage area, the curve may be used to study the characteristics of a drainage basin or to compare the characteristics of one basin with those of another. A curve with a steep slope throughout denotes a highly variable stream whose flow is largely from direct runoff, whereas a curve with a flat slope reveals the presence of surface- or ground-water storage, which tends to equalize the flow. The slope of the lower end of the duration curve shows the characteristics of the perennial storage in the drainage basin; a flat slope at the lower end indicates a largo amount of storage; and a steep slope indicates a negligible amourt. Streams whose high flows come largely from snowmelt tend to have a flat slope at the upper end. The same is true for streams with large flood-plain storage or those that drain swamp areas.

The statistics of the duration curve are discussed in papers by Foster (1924, 1934), Slade (1936), Beard (1943), and others. The work of Elderton (1953) also contains valuable informetion on the statistical and mathematical basis of the duration curve. Such a discussion is beyond the scope of this chapter.

\section{MEAN}

The area under the flow-duration curve is a measure of the discharge available 100 percent of the time. Dividing the area by 100 (base of the curve-100 percent of the time) gives the average ordinate which, multiplied by the scale factor (see sectior on waterpower studies), is the mean discharge. Similarly, the area under a portion of the curve, divided by the percent of time of that portion, represents the mean flow during the particular percent of time. This property of the curve has important applications in scme studies, but finding the scale factor of a flow-duration curve plot,ted on logarithmic-probability paper is somewhat complicated.

\section{MEDIAN}

The median flow is the curve value at 50 percent of the time.

\section{MODE}

The point of inflection of a flow-duration curve plotted on rectangular-coordinate paper occurs at the modal flow. This inflestion point can be detected on figure 10, where the frequency curve of a hypothetical stream has been plotted with its flow-duration curve. However, the inflection point of a flow-duration curve is usually not 
definite enough for determining accurately the modal flow from the flow-duration curve and, when logarithmic and probability scales are used for plotting, the mode does not fall at the apparent inflection point.

The modal value has been suggested (Meyer, 1928, p. 119) as an appropriate "normal" flow, as it is the flow that occurs most often.

\section{USES OF THE FLOW-DURATION CURVE}

As early as 1908, Mead (1908, p. 184-189) presented flow-duration curves in cubic feet per second per square mile for six Michigan rivers to show their similarity, and, at the same time, to point out the error that might result from estimating the flow of an ungaged stream. Mead states, "This form of diagram represents the best basis for the comparative study of streamflow for power purposes where $s^{+}$orage is not considered, and where the continuous power of the passing stream is to be investigated."

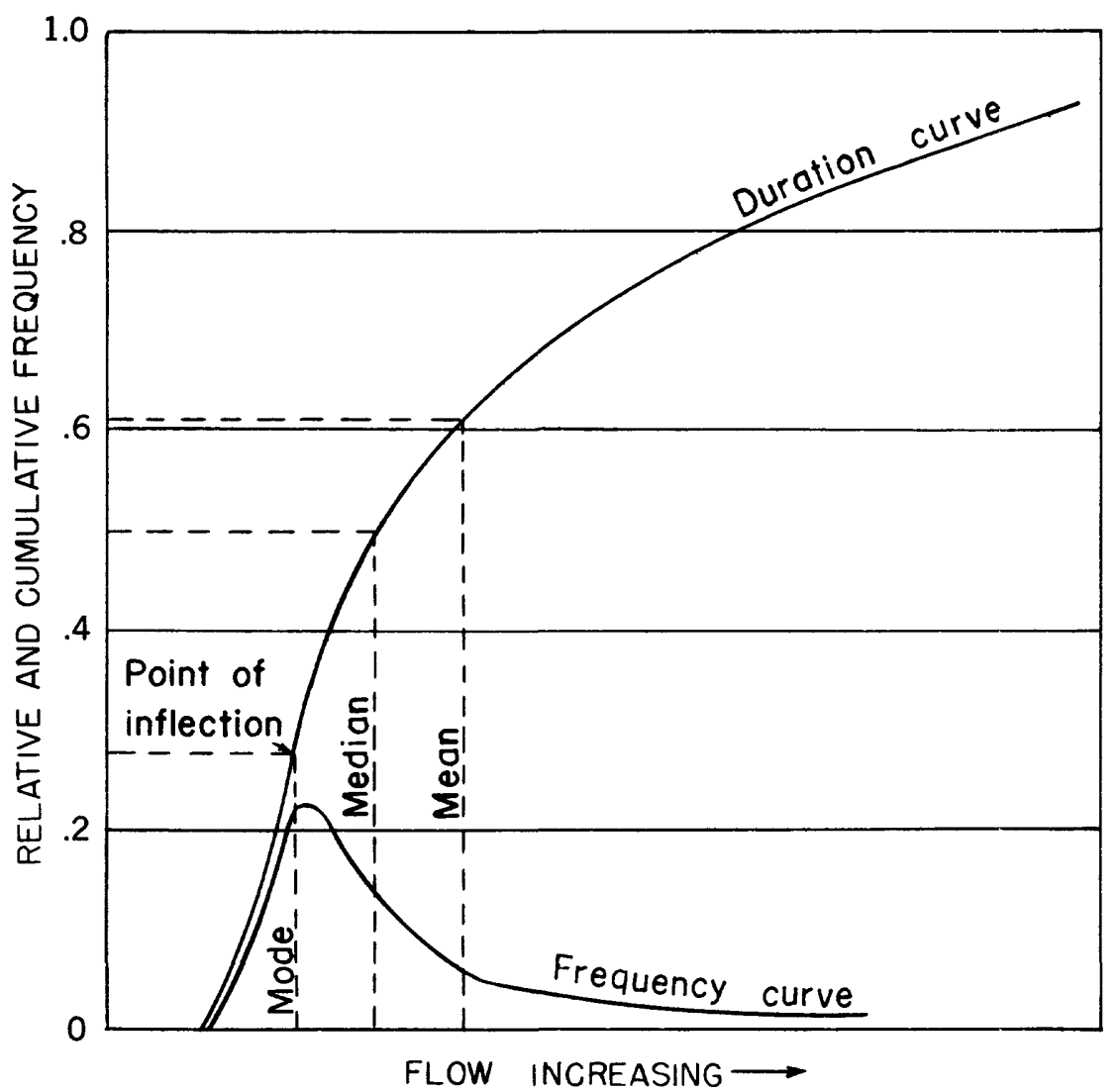

Figure 10.- Relation of duration and frequency curve. 
It was not until about 1915, however, that flow-duration curves came into general use in the United States, and about 1920 the Geological Survey adopted the flow-duration curve as a basis for defining rates of flow to be used in computing waterpower statistics.

In 1930 the International Advisory Committee on Rating of Rivers adopted certain percent-duration points for quoting power statistics. W. G. Hoyt (1934, p. 1240-1243) stated that "It is doubtful whether agreement could have been reached on the basis of any defined rates of flow other than those obtained through the use of the duration curve."

One of the earliest uses of the flow-duration curve was for waterpower studies. The subject is discussed by many writers, among whom are Barrows (1943, p. 137-192), Hickox and Wessenauer (1933), and Foster (1934).

Beard (1943) and Pettis (1934, p. 1237-1240) have applied the upper end of the flow-duration curve to flood studies.

More recently the flow-duration curve has been used for preliminary investigations of water supply, location of industrial plants, pollution studies, and many other purposes. Simple examples of a few uses of the flow-duration curve are given in the following sections.

\section{STUDYING THE EFFECT OF GEOLOGY ON LOW FLOWS}

The flow-duration curve is a valuable medium for studying and comparing drainage basin characteristics, particularly the effect of basin geology on low flows. Except in basins with a highly permeable surface, the distribution of high flows is governec largely by the climate, the physiography, and the plant cover of the linsin. The distribution of low flows is controlled chiefly by the geology of the basin. Thus, the lower end of the flow-duration curve is a valuable means for studying the effect of geology on the ground-water runoff to the stream. Where the stream drains a single formation, the position of the low-flow end of the curve is an index of the contribution to streamflow by the formation. The effect of geology on low flow in Ohio has been discussed by Cross (1949), Cross and Bernhagen $(1949$, p. 5), and Schneider (1957).

Six streamflow records for southern Mississippi are used to illustrate the effect of geology on low flow. The area selected has a fairly uniform climate and little difference in elevation. The map showing outcrops of the principal formations (fig. 11) is adapted from plate 2, Water-Supply Paper 576 (Stephenson ind others, 1928). Details, such as variations within the prinicpal formation outcrop and outcrops within the immediate vicinity of the streams, have been omitted. 
Descriptions of the formations (from pl. 2, WSP 576) are as follows :

Citronelle formation_-_Sand, gravel, and clay.

Catahoula sandstone_-_Irregularly bedded sand, sandstone, and clay.

Vicksburg group _-_-_Limestone, marl, clay, and sand.

Jackson group bedded in quartz sand and glauconite; upper portion Yazoo clay-clay, more or less calcareo'ns, with some sand and marl.

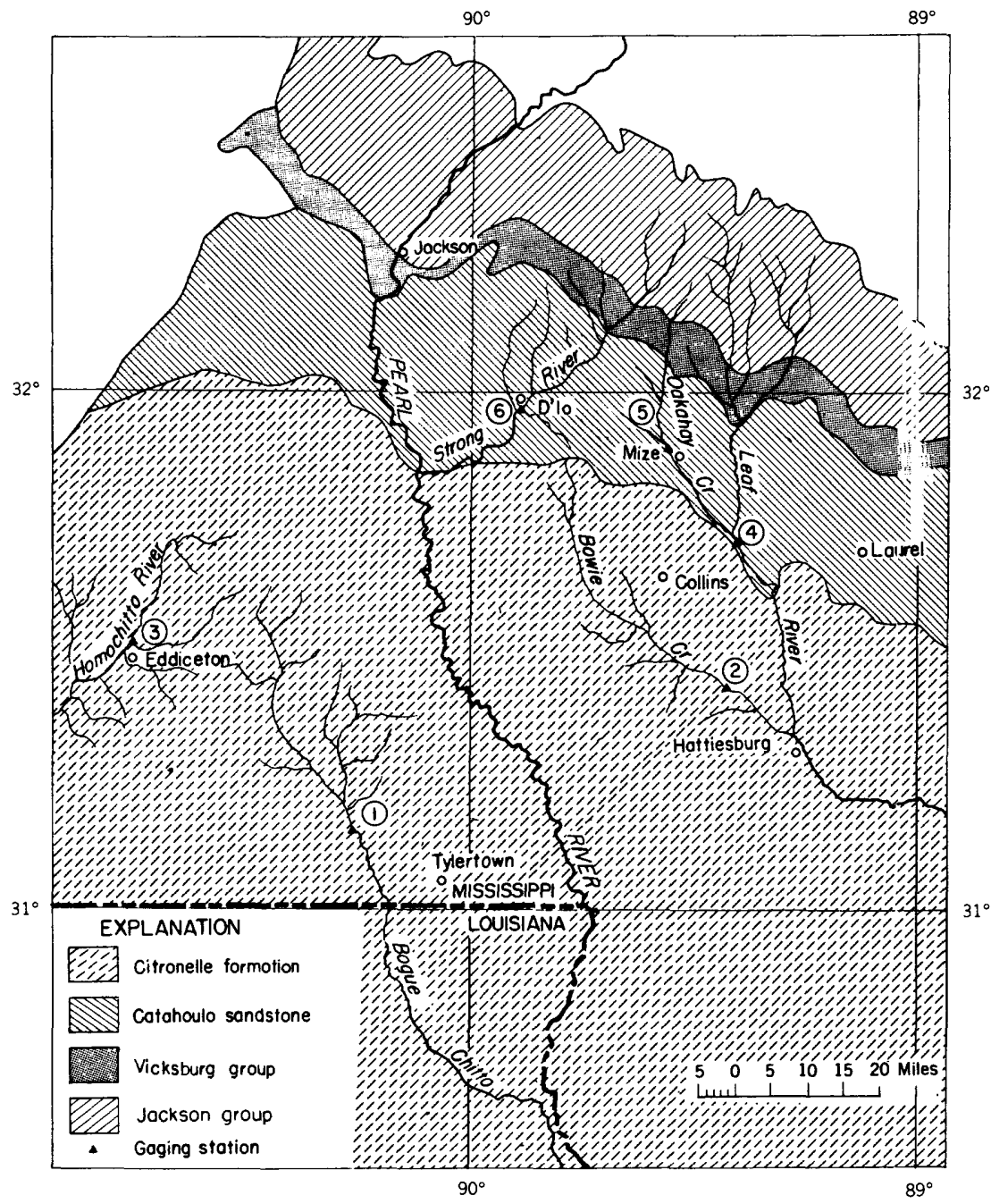

Figure 11.-Geologic map of area in southern Mississippi having approximately untform climate and altitude. 
Figure 12 shows flow-duration curves for six southerr Mississippi streams plotted from data in "Surface Waters of Mississip ni" (Anderson, 1950). Curves 1, 2, and 3 represent streams drainirg the Citronelle formation outcrop; curves 4, 5, and 6 represent streams that contain outcrops from the Catahoula sandstone, the Vicksburg group, and the Jackson group.

It is apparent from figures 11 and 12 that streams draining the same geologic formations have more nearly the same low-flow duration in cubic feet per second per square mile than nearby streams draining different geologic formations. For example, tha flow-duration curve for Bowie Creek (curve 2 on figures 11 and 12) more nearly resembles the curve for Bogue Chitto (curve 1) than that of the nearby Leaf River near Collins (curve 4).

Where the yield per square mile to streamflow from adjacent geologic formations differs greatly, the index stations, to be used with discharge measurements at base-flow observation points, should measure single geologic formations whenever possible. In some drainage basins containing several formations, it may be possible to estimate the average yield per square mile of the whole basin by adding the proportional contribution of each geologic formation.

This discussion has been oversimplified to illustrate the principles involved. Even if the geologic formation is the same throughout a basin, other factors, such as variations in permeability of the formation, the character of the underlying formation, and the depth of incision of the stream, affect the low-flow characteristics at a particular point on a stream. For example, although the streams represented by curves 1, 2, and 3 (fig. 12) all drain from the Citronella formation, curve 3 differs greatly from curves 1 and 2.

This discussion of the effect of geology on streamflow provides a warning against estimating low flow from ungaged aras without carefully studying the area and making base-flow meas'rements at several different points. In such a study, knowledge of the geology of a basin can seldom be used to make quantitative estimates of lowflow potential of streams, but it will help to explain the differences.

\section{WATERPOWER STUDIES}

The flow-duration curve is used for preliminary studies of plant capacity, economic feasibility of projects, and pondage (Barrows, 1943 ; p. $159-191$ and Foster, 1934; p. 1230-1234). Its use in a multiple-plant development is discussed by Hickox and Wessenauer (1933).

As a simple example, assume that a "run of the river" hydroelectric plant is at a site with a net head of 100 feet and that the 
flow-duration curve is the one shown in figure 13. The tertative turbine capacity is $6,000 \mathrm{cfs}$. The preliminary study requires an estimate of the average yearly output in million kilowatt-hours at the wheel shaft for primary and for secondary power, assuming 80percent turbine efficiency, a load factor of 100 percent, and no loss or waste of power.

The area below the duration curve and the turbine capacitr line represents the flow available for producing power. Flow in excess of $6,000 \mathrm{cfs}$ cannot be used by the turbine. The scale factor (value of each small square) can be determined by computing the number of squares (500) that represents $1,000 \mathrm{cfs}, 100$ percent of the tim?. In figure 12 the scale value of each square is 1,000 (cfs) divided $\mathrm{Iy} 500$ (squares), or 2 cfs for each square.

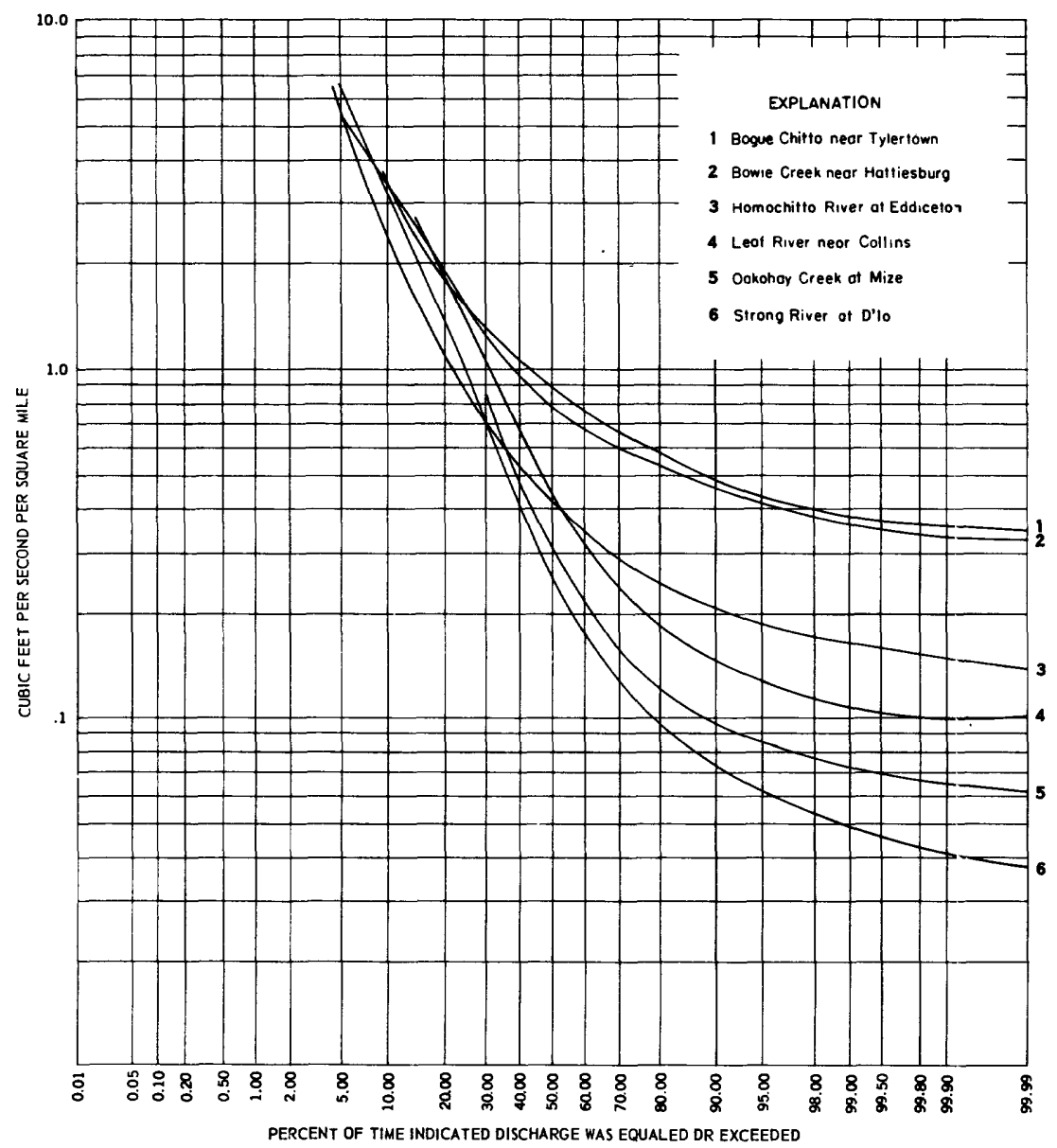

FIgOR: 12.-Flow-duration curves for selected Mississippi streams, 1939-48. 
The average yearly output at the wheel shaft for $1 \mathrm{cfs}$, with 80 percent efficiency and with a 100 -ft head, is computed as follows:

$$
\frac{62.4 \times 100 \times .80 \times 6535}{550}=59,338 \text { (kilowatt-hours) }
$$

The upper limit of primary power (power available continuously) is the horizontal line through the minimum flow ( $800 \mathrm{cf}:$ in this example). Thus, the primary power is $800(\mathrm{cfs}) \times 59,338=47.5$ million

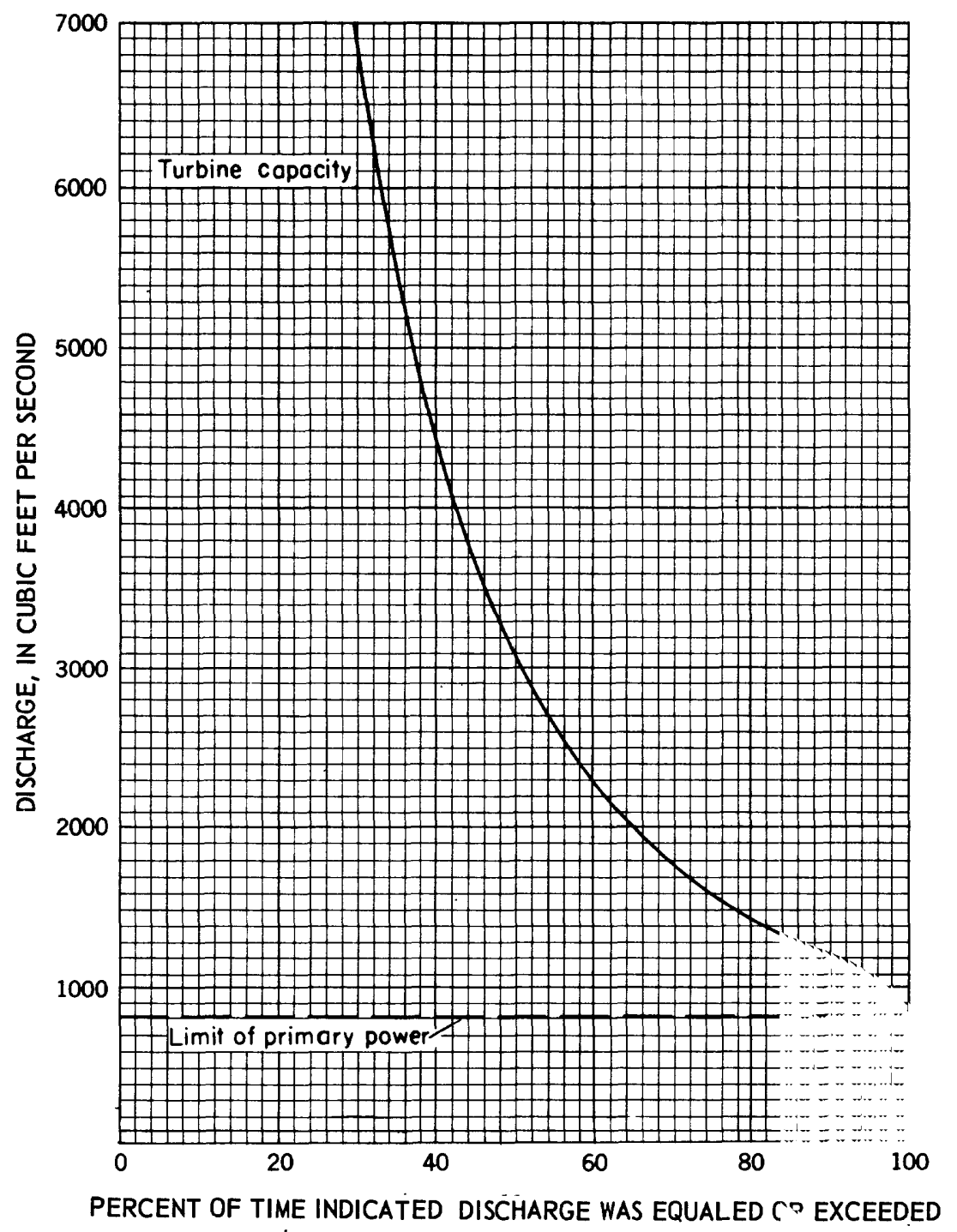

Figuri 13.-Flow-duration curve applied to hydropower study. 
kilowatt-hours yearly. The discharge available to produce secor -lary power is represented by the area bound by the upper limit of primary power, the turbine-capacity line, and the flow-duration curve. This area is determined by planimetering, by counting squares, or by scaling. In the example, the area is 1,380 squares and the flow is 2,760 cfs $(2 \times 1,380)$. The secondary power is thus

\section{$59,338 \times 2,760=163.8$ million kilowatt-hours yearly}

\section{STREAM-POLIUTION STUDIES}

To illustrate the use of the flow-duration curve in a preliminary analysis of the degree of treatment required, the following data are assumed :

1. No contamination above point under investigation.

2. Allowable BOD (biochemical oxygen demand) for stream below the disposal plant is $4 \mathrm{ppm}$.

3. The allowable BOD ( $4 \mathrm{ppm})$ may be exceeded not more than

1 percent of the time, on the average.

4. Flow equals or exceeds $10 \mathrm{cfs} 99$ percent of the time.

5. Sewage flow is $1,000,000$ gallons per day $(1.55 \mathrm{cfs})$.

6. BOD of untreated sewage is $200 \mathrm{ppm}$.

Compute the degree of treatment required:

The allowable BOD below disposal plant outlet $=4 \mathrm{ppm} \times(10$ cfs $+1.55 \mathrm{cfs}$ ).

The BOD of the sewage $=200 \mathrm{ppm} \times 1.55 \mathrm{cfs}$.

The degree (D) of BOD not removed by treatment $(\mathrm{D} \times 200 \times 1.55)$ must not exceed the allowable $(4 \times 11.55)$ or $\mathrm{D}=\frac{4 \times 11.55}{200 \times 1.55}=0.15$ or 15 percent. Thus, 85 percent of the BOD must be removed by the sewage disposal plant.

\section{QUALITY-OF-WATER STUDIES}

The quality of surface streams is often shown by duration curves of sediment, turbidity, hardness, or some other quality-of-water characteristic. These duration curves are obtained in a manner similar to that described for flow-duration curves.

If the quality-of-water data are insufficient for direct computation of some descriptive statistics, such as frequency distribution, annual loads, annual average concentrations, and standard deviations, flowduration curves can be used sometimes to make approximations. The suitability of this technique is dependent on the correlation of the quality characteristics against stream discharge. The error of the approximation includes both the error of the flow-duration curre and the error of estimate for the correlation. 
For each sample, the quality-of-water characteristic to be shown is plotted against the stream discharge at the time of collection. A rating curve of quality-of-water characteristic versus discharge is drawn to average the plotted points. The duration curve of streamflow is converted to a curve showing frequency of a specified quality characteristic by looking up the discharge at several percont-duration points and obtaining the corresponding value of the quality-of-water characteristic from the rating curve. These values are plotted against the appropriate percent of time to obtain points for drawing the quality-of-water frequency curve. The quality-frequency curve developed thus is divided into convenient segments or groups, and the desired statistical description is computed in the customary manner.

\section{VARIABILITY INDEXES}

An important characteristic of the flow of a stream is its variakility. Variability of streamflow is the result of variability in precipitation as modified by basin characteristics. Storag?, either on the surface or in the ground, serves to reduce the variability of flow. As an illustration of the range in variability of streans, the May 1955 flow of a station in Michigan was among the lowest. 25 percent of record although the flow was 93 percent of the median, whereas at a station in California the flow was not among the lowest 25 percent of record although it was only 10 percent of the modian.

The slope of the flow-duration curve is a quantitative measure of the variability. Several indexes of this slope have been used. In 1920 the Geological Survey adopted the flow available 50 percent of the time $\left(q_{50}\right)$ and the flow available 90 percent of the time $\left(q_{90}\right)$ as standards of flow for waterpower statistics. The $q_{90}$ is a measure of the prime power and the $q_{50}$ is an index of the power potential with storage. Together, the two indicate the variability of fow.

\section{LANE'S VARIABILITY INDEX}

Lane and Lei (1950) introduced an index of variability, which was defined as the standard deviation of the logarithms of the stream discharge. On log-probability paper this index represents the fall (in terms of log cycles) of the duration curve in one stantard deviation. The index can be estimated by scaling the value from a plot on logarithmic paper, or it can be computed as follows: 
1. From the duration curve, pick values of discharge at 10-percent intervals from 5 percent to 95 percent of the time.

2. Look up the logarithms of these discharges and compute the standard deviation of the logarithms (index of variability) :

a. Obtain mean of the logarithms.

b. Compute differences of each of the 10 logarithms from the meen.

c. Square the differences.

d. Obtain the sum of the squares.

e. Divide the sum of the squares by 9 .

f. Extract the square root of the results of step e.

Lane and Lei (1950) discussed the use of their variability index in studying streamflow characteristics and proposed that an estimated variability index be used with an estimated mean annual discharge to produce a synthetic flow-duration curve. They found that large drainage areas tended to have lower values of variability than small ones.

Mitchell (1957, p. 161-166) found that, for Illinois, Lane's variability index differed considerably from one region to another, yet when the values of the index were plotted on a map, a consistent pattern was observed. The map of Illinois showing regional values of the variability index was presented for use in deriving synthetic duration curves for unmeasured areas.

A synthetic duration curve based on an estimated variability index and an estimated median flow may be accurate for the portion of the flow-duration curve that plots as a straight line on log-probebility paper. Likewise, a duration curve, drawn as the average of the duration curves of nearby gaged streams draining areas that are apparently similar, may be reliable considerably below the median point but may depart radically at the extreme low end. Tro end points of the flow-duration curve cannot be accurately determined from the slope of the straight portion of the flow-duration curve. This statement can be verified for the low-flow end by studying the flow-duration curves of figure 12 and the location of the gaging stations on figure 11. Although the end portions of the flow-duration curve occupy a sizable space on probality paper, the percentrge of time during which the inaccurately determined flows occur is small, and for some studies a synthetic curve may be suitable. When the extreme low end of the flow-duration curve is important, bas?-flow measurements should be made at the unmeasured site and correlated with the concurrent discharge at a stream-gaging station. ( $\mathrm{S}^{a} \boldsymbol{e}$ the section on estimation of the flow-duration curve.) 


\section{RELIABILITY OF AN INDIVIDUAL STATION RECORD}

A gaging-station record, however long, represents only a small sample of the long-term flow characteristics of the stream. Tr $:$ reliability of the record for predicting the behavior of the stream depends upon the accuracy and consistency of the record and upon how well the period of record represents the long-term flow of the stream.

The need for accurate records of basic data is obvious, but consistency of the record often does not receive enough emph isis. A 30year record collected during 10 years of natural flow ccnditions, 10 years of irrigational or storage developments, and 10 years under changed basin conditions cannot serve as the basis for prodicting future flows. Other major changes in the basin also affect the record. Changes in gage location or measuring section, even without appreciable change in drainage area, can affect the consistency of the record. This is particularly true of areas underlain by limestone, where low flows vary widely within short reaches of the same stream. Before analysis, records should be examined for consistency and the drainage basin history should be studied for information on developments that might affect the consistency of the record.

Even though a gaging-station record is accurate and consistent, it may not be representative of the long-term flow of the stream. This is particularly true of short-term records, which may include a predominance of dry or of wet years. Duration curves for such records should be adjusted to a long-term period by correlation with records at a long-term gaging station.

If no long-term gaging station record for an area is available, a regional analysis of all the short-term records for the area will improve the reliability of each of the flow-duration curves. A regional analysis of flow-duration data consists of (a) establishing a relation (as in fig. 7) between each individual station and a "pirot" station, (b) transferring the flow-duration curve of each individual station to the pivot station by using the curve of relation, (c) drawing an average or composite curve for the pivot station, and (d) transferring the composite curve of the pivot station back through the curve of relation to the individual station.

Regional analysis modifies the individual gaging-station record so that a chance occurrence of an event, such as a local shc wer during an extreme drought in a particular drainage basin, will not unduly affect the analysis. Likewise, regional analysis takes into account the failure of such an event to occur within a particuler drainage basin when the event did occur within other basins in the region. 


\section{REFERENCES CITED}

Anderson, I. E., 1950, Surface water of Mississippi : Mississippl Geol. Survey Bull. 68, 338 p.

Barrows, H. K., 1943, Water power engineering: 3d ed., New York, McGrawHill Book Co., 791 p.

Beard, L. R., 1943, Statistical analysis in hydrology : Am. Soc. Civil Enrineers Trans., v. 108, p. 1110-1160.

Cross, W. P., 1949, The relation of geology to dry-weather stream flow in Ohio: Am. Geophys. Union Trans., p. 563-566.

Cross, W. P., and Bernhagen, R. J., 1949, Ohio stream-flow characteri-ticsPt. I, Flow duration: Ohio Dept. Nat. Resources, Div. Water Bill. 10.

Elderton, W. P., 1953, Frequency curves and correlation: 4th ed., Washington, D.C., Harren Press, 272 p.

Foster, H. A., 1924, Theoretical frequency curves and their application to engineering problems: Am. Soc. Civil Engineers Trans., v. 87, p. 142-203. 1267.

Hickox, G. H. and Wessenauer, G. O., 1933, Application of duration curves to hydro-electric studies: Am. Soc. Civil Engineers Trans., v. 98, p. 127i-1308.

Hoyt, W. G., 1934, Discussion of duration curves by H. A. Foster: Am. Soc. Civil Engineers Trans., v. 99, p. 1240-1243.

Lane, E. W. and Lei, Kai, 1950, Stream flow variability: Am. Soc. Civil Engineers Trans., v. 115, p. $1084-1134$.

Mead, D. W., 1908, Water power engineering : 1st ed., New York, McGraw-Hill Book Co., $787 \mathrm{p}$.

Meyer, A. F., 1928, The elements of hydrology : $2 d$ ed., New York, John Wiley and Sons.

Mitchell, W. D., 1950, Water-supply characteristics of Illinois streams: Jllinois Dept. Public Works and Bldgs., Div. Waterways, 311 p.

- 1957, Flow-duration of Illinois streams : Illinois Dept. Public Wor's and Bldgs., Div. Waterways, 189 p.

Pettis, C. R., 1934, Discussion of duration curves by H. A. Foster : An. Soc. Civil Engineers Trans., v. 99, p. 1237-1240.

Saville, Thorndike, and Watson, J. D., 1933, An investigation of flow-drration characteristics of North Carolina streams: Am. Geophys. Union Trans., p. 406-425.

Schneider, W. J., 1957, Relation of geology to streamflow in the upper Little Miami basin: Ohio Jour. of Science, v. 57, No. 1, p. 11-14.

Slade, J. J., Jr., 1936, An asymmetric probability function: Am. Soc. Civi Engineers Trans., v. 101, p. 35-104.

Stephenson, L. W., Logan, W. N., and Waring, G. A., 1928, The ground-water resources of Mississippi: U.S. Geol. Survey Water-Supply Paper :76. 